with the existing Suez Canal. Under Said Pasha he was appointed bead of the Ponts et Chansées department, and chief engineer of the Suez Canal project. In early lite he travelled much in Abyssinia, Kordofan, and Darfur.

Sir Claude de Crespigny, in company with Mr. Simmons, made a successful balloon voyage from Maldon in Essex across the North Sea to Flushing on Wednesday last week. The start was made at II a.m., and Flushing was reached about 8 p.m. The highest altitude reached was 17,000 feet.

WAUSCHAFF of Berlin has lately made a piece of apparatus for registering earth currents. It consists of a very delicate galvanometer inclosed in a case with a clockwork arrangement for moving a photographic plate steadily downwards. A fine ray of light is reflected on to the galvanometer mirror by a total reflection prism and is focused on the photographic plate. The speed of the movement of the plate is $80 \mathrm{~mm}$. per hour, thus allowing variations from $m$ inute to minute to be observed.

MM. LELANDE AND ChAPERON have brought out a new battery of very remarkable properties. The battery is a single liquid cell and has a depolarising electrode of oxide of copper, the liquid used is caustic potash, and the other pole is zinc. The battery is made in various forms, its E.M.F. is nearly I volt, whilst it is said to give a steady current through even a low resistance for many hours. Finally it is claimed for this battery that when exhausted it can be restored by driving a current from an accumulator through it.

A NEW edition (the fifth) is announced of the "Dictionnaire des Arts et Manufactures et de l'Agriculture," edited by M. Ch. Laboulaye.

Mr. Browne asks us to say that in his recent article on Glacier Motion, p. 235, by a slip of the pen he stated that the sides of a glacier move faster than the middle, whereas, as every one knows, the reverse is the case.

THE additions to the Zoological Society's Gardens during the past week include a Grivet Monkey (Cercopithecus griseo-viridis o) from West Africa, presented by Lord Hastings; two Blackbackel Jackals (Canis mesomelas), two Triangular Pigeons (Columba gzinea) from South Africa, presented by Mr. R. Southey; two Indian Brush-tailed I'orcupines (Atherura fasciculata) from Ceylon, presented by Mr. A. Dent; three Puffins (Fratercula arctica), British, presented by Mr. H. Becher; a Common Cormorant (Phalacrocorax carbo), British, presented by Mr. W. R. Temple; a Common Barn Ow1 (Strix fammea), British, presented by Mr. H. Hanaeur; a Common Wombat (Phascolomys wombat of) from Tasmania, a Common Cormorant (Phalacrocorax carbo), British, a Common Boa (Boa constrictor) from West Indies, deposited; a White Stork (Ciconia alba), two Common Spoonbills (Platalea leucorodia), two Purple Herons (Ardea purpurea), European, purchased ; a Musk Deer (Moschus moschiferus $\delta$ ) from Central Asia, received on approval; a Collared Fruit Bat (Cynonycteris collaris), two Amherst's Pheasants (Thaumalea amherstia), two Summer Ducks (Aix sponsa), bred in the Gardens.

\section{A CONTRIBUTION TO THE STUDY OF THE TRANSMISSION EASTWARDS ROUND THE GLOBE OF BAROMETRIC ABNORMAL MOVEMENTS}

IN his paper on "Abnormal Variations of Barometric Pressure in the Tropics, and their Relation to Sun-spots, Rainfall, and Famines," published in NATURE (vol. xxiil. pp. 88 and I07), Mr. Fred. Chambers pointed out, when treating of the barometric records of the stations, St. Helena, Mauritius, Bombay, Madras, Calcutta, Batavia, and $\mathrm{Zi}$-ka-wei, that abnormal movements which had occurred at a westward station-e.g. Mauritiusreappeared at an eastern station-e.g. Bombay-some time later, and then again at a further eastern station, Madras, still later, and so on, until they finally reached the most distant station eastwards. It appeared therefore that there were abnormal movements of the atmospheric pressure which travelled from west to east ; the rate of travel seemed to vary at different times; and Mr. Chambers summed up his recults in the following words :"It appears then that these atmospheric waves (if such they may be called) travel at a very slow and variable rate round the earth from west to east like the cyclones of extra-tropical latitudes."

In bis "Brief Sketch of the Meteorology of the Bombay Presidency in 1880, , Mr. Chambers proceeded to test the validity of his conclusions by applying them to an examination of the barometric records of Zanzibar for that year and a portion of the next as compared with the records of Belgaum for the same period; and he again noticed that "there was much similarity in the abnormal movements of barometric pressure at Zanzibar and Belgaum, although these stations are about 2500 miles apart, but that the Belgaum curve lagged decidedly from two to three menths behind the Zanzibar curve."

This discovery, if substantiated, would obviously prove of great practical value, inasmuch as it would make it possible to obtain a forecast of the barometric movements about to occur at any particular station by watching the movements already taking place at a point westward of that station. And as definite variations in the atmospheric pressure may be, and in some cases are known to be, accompanied by definite variations in the other meteorological elements, a method of weather prediction would thus be furnished.

It has fallen to my lot to receive and discus; the Zanzibar observations succeeding those last discussed by Mr. Chambers ; and the results obtained by my examination of them seem to involve matters of some practical and theoretical interest.

TABLE I.-Monthly Abnormal Barometric Pressure at Zanzibar, Belgaum, and Bombay

\begin{tabular}{|c|c|c|c|c|c|c|}
\hline \multirow{2}{*}{ Months. } & \multicolumn{3}{|c|}{$\begin{array}{l}\text { Monthly Abnormals } \\
\text { (unsmoothed). }\end{array}$} & \multicolumn{3}{|c|}{$\begin{array}{l}\text { Monthly Abnormals } \\
\text { (sm sothed). }\end{array}$} \\
\hline & Zanzibar & Belgaum & Bombay & Zanzibar & Belgaum & Bombsy \\
\hline February 1880 & -.014 & -.024 & '000 & - & - & - \\
\hline March , , & -005 & -013 & $-{ }^{\circ} \mathrm{O} 2 \mathrm{O}$ & -.004 & -.017 & - OII \\
\hline April & +008 & $-\mathrm{O} 22$ & -006 & +003 & -.0 & $\ldots .010$ \\
\hline May & +005 & -0 & $-\cdot 008$ & +.006 & -.0 & -.002 \\
\hline June & $+\infty 008$ & $-{ }^{\circ} 008$ & +015 & $+\cdot 018$ & -1009 & +014 \\
\hline July & +.054 & + OII & $+\circ 35$ & +034 & +0 & $+{ }^{\circ} \mathrm{c}$ \\
\hline August & +022 & $+\operatorname{or} 5$ & $+04 I$ & +.034 & $+\circ$ & $+{ }^{\circ} 0_{3} \mathrm{O}$ \\
\hline September,", & $+.03^{8}$ & $-\mathrm{OOI}$ & +.006 & +035 & $+{ }^{\circ} 0$ & +017 \\
\hline October ,", & $+\circ 044$ & +015 & + or 9 & +.038 & +008 & +013 \\
\hline November, & +.026 & +.003 & + OIO & +.031 & +0 & + \\
\hline December , & +.028 & +037 & $+\cdot 040$ & +025 & $+0 \mathrm{O} 5$ & +029 \\
\hline January I88I & +018 & +0 & +.029 & +.019 & +027 & +033 \\
\hline February , & $+\circ 014$ & +02 & +037 & +.009 & +0 & +033 \\
\hline March & -007 & +00 & +.032 & +005 & +.007 & +030 \\
\hline April & +.023 & -.008 & +.020 & +.005 & -.005 & + oIs \\
\hline$y$ & -017 & -013 & $\frac{1}{5} \cdot \mathrm{OOI}$ & +.003 & -.007 & +017 \\
\hline June & $+{ }^{\circ} \mathrm{O} 24$ & +.005 & +049 & +013 & +.002 & $+0_{3} x$ \\
\hline July & +025 & $+\mathrm{OI}_{3}$ & +028 & +019 & $-{ }^{\cdot} 003$ & +022 \\
\hline August , & +.003 & $-0_{4} 6$ & -.016 & +.017 & -.020 & 000 \\
\hline September," & +037 & -.004 & $+\infty 05$ & +.021 & - .017 & .000 \\
\hline October & +.009 & -014 & +.004 & +.002 & $-{ }^{\circ} \mathrm{O} 20$ & -.006 \\
\hline November,", & -.047 & -.051 & -.037 & $-{ }^{\circ} 024$ & -.035 & -023 \\
\hline December, & -014 & -028 & -024 & - OI 5 & -020 & -010 \\
\hline January 1882 & $+\mathrm{O} 2$ & +026 & +.029 & -.005 & $+\circ \infty$ & $+\circ \mathrm{OI} 4$ \\
\hline dary , & -.033 & -017 & +010 & -.016 & -.003 & + or 4 \\
\hline March & $-\mathrm{OI} 2$ & -.003 & + OI $x$ & - OII & $-\operatorname{or} 5$ & +.004 \\
\hline April & $+\cdot 012$ & -040 & - .016 & .000 & -.026 & -002 \\
\hline May & $-\cdot 009$ & -.024 & + oI & $+\cdot 002$ & -.026 & $+\infty 01$ \\
\hline June & +017 & - 018 & -.002 & +oI 6 & -.023 & -.003 \\
\hline & +040 & -.034 & -.019 & $+.03 r$ & -025 & -.005 \\
\hline August , , & $+\circ 029$ & -.014 & $+\mathrm{O} 20$ & $+\circ 027$ & - 'org & +.004 \\
\hline September,, & +012 & -015 & -.002 & - & - & - \\
\hline
\end{tabular}

From these observations the variations from the normal monthly barometric movements have been obtained. They are tabulated in Table I, and are represented graphically by the 
thin dotted line of the lowest curve in the accompanying plate. Alongside of them are arranged, both in the table and the plate, the barometric abnormal movement of the meteorological stations, Belgaum and Bombay. In order to facilitate comparisons between the curves of these three stations the actual normal movements, which are represented in the plate by thin dotted lines, have been put through a double process of smoothing; the results are tabulated under the heading of "Monthly Abnormals (smoothed)," and are represented on the plate by the thick con. tinuous lines. The observations not previously discussed are those taken from June, I88I, to September, I882, of all the stations, together with the Bombay record from February, I880, to June, I88I.

The addition of this series to the Zanzibar record seems to confirm. the result of previous observations, viz. that there are abnormal movements of the atmospheric pressure which affect

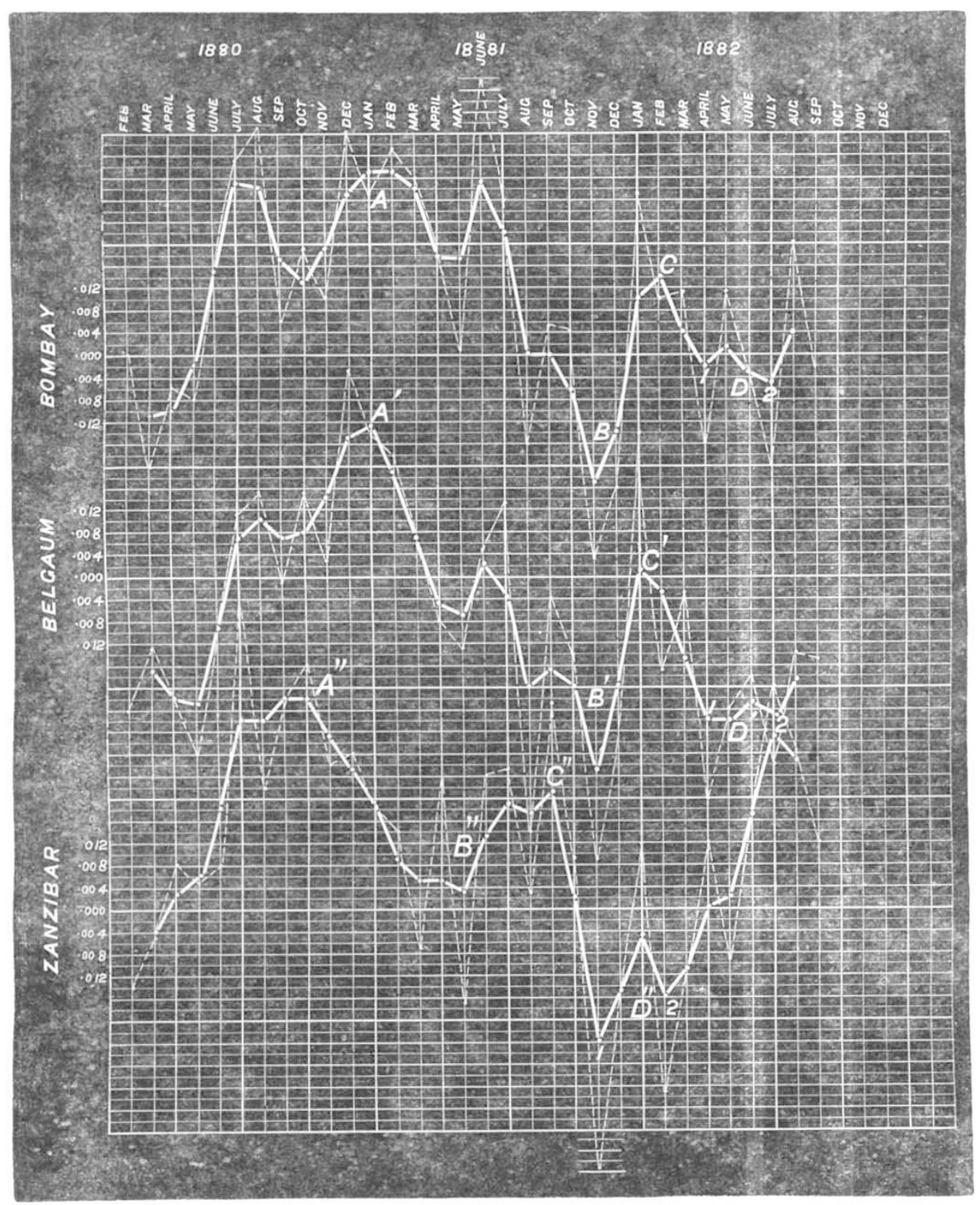

a very wide area, and which are not simultaneous in all parts of that area, but travel from west to east. An inspection of the smoothed curve will show what amount of truth there is in this statement. Thus the Zanzibar curve shows an upward bend at $A^{\prime \prime}$ and a downward bend at $\mathrm{B}^{\prime \prime}$, a second upward bend at $\mathrm{C}^{\prime \prime}$, and a second downward bend at $b^{\prime \prime}$. The Bombay and Belgaum curves both show a similar general form, having upward bends at $\mathrm{A}$ and $\mathrm{A}^{\prime}$ corresponding with the upward bend $\mathrm{A}^{\prime \prime}$ of the
Zanzibar curve, downward bends $\mathrm{B}$ and $\mathrm{B}^{\prime}$ corresponding with the downward bend $\mathrm{B}^{\prime \prime}$ of the Zanzibar curve, and similarly $\mathrm{c}, \mathrm{C}^{\prime}$ and $\mathrm{D}, \mathrm{D}^{\prime}$ corresponding with $\mathrm{C}^{\prime \prime}$ and $\mathrm{D}^{\prime \prime}$ of Zanzibar. And it is at 0 ce seen that the movements at Zanzibar are in advance of those of Bombay and Belgaum. Thus the Zanzibar maximum $\mathrm{A}^{\prime \prime}$ took place in October, 1880 , whilst the corresponding movements did not appear at Belgaum until the month of January, $\mathbf{I} 88 \mathrm{I}$, and at Bombay until between January and February, 
$188 \mathrm{I}$; that is to say, at periods of three and three and a half months later. Then again the minimum movem nt $\mathrm{B}, \mathrm{B}^{\prime}$, and $\mathrm{B}^{\prime \prime}$ which occurred at Zanz bar in the month of May, I88r, did not appear at Boinbay and Belgaum until the month of November of the same year; that is to say, after an interval of six months. Again, the maximum movement $\mathrm{c}, \mathrm{c}^{\prime}$, and $\mathrm{c}^{\prime \prime}$ occurred at Zanzibar in the month of September, I88I, but not at Lelgaum until January, I882, and at Bombay until February, 1882 ; that is to say, until after intervals of four and five months respectively. Again, on examining the minimum $\mathrm{D}, \mathrm{D}^{\prime}$, and $\mathrm{D}^{\prime \prime}$, which is divisible into two minor minima, the first of these minor movements appears at Zanzibar in the month of November, I88I, but at Belgaum between the month of April and May, and at Bombay in the month of April, 1882 ; that is to say, after intervals of five and a half and five months respectively. Lastly, the second minor movement of the minimum $\mathrm{D}, \mathrm{D}^{\prime}$, and $\mathrm{D}^{\prime \prime}$ occurred at Zanzibar in the month of February, I882, and at Belgaum and Bombay in July of the same year; that is, after an interval of five months.

These facts may be presented briefly and concisely thus :-

TABLE II.

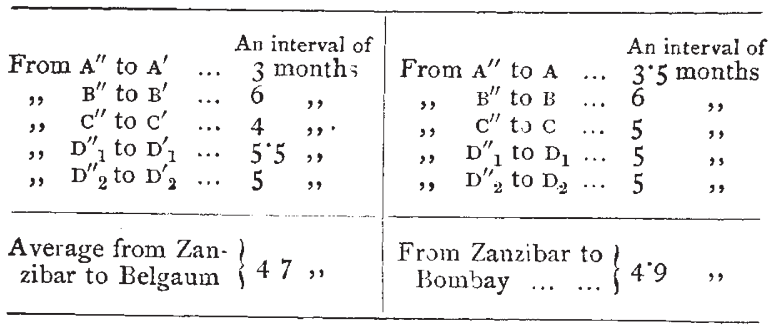

In the case before us, then, it does appear to be matter of fact that there are movements tahing place at the two stations, Belgaum and Bombay, similar in character to movements which have taken place at Zanzibar on an average about five months previously. And assuming that the same cour:e of events will occur in the future, it may be expected that from the month of August to the month of December, 1882, the abnormal variations of the barometer at Bombay and Belgaum will in a general way follow the same course as was taken by the variations at Zanzibar during the months of April, May, June, and July; that is to say, an upward movement.

This prediction might be considered fairly reliable to within about a month one way or the other, were there no modifying conditions. But the curves are seen at a glance to present most decided departures from absolute parallelism; there are movements at Zanzibar which do not reappear at the eastern stations, whil:t the eastern stations experience movements which do not appear to have been previously experienced at Zanzibar. Moreover, the rate of transmission of movements from Zanzibar to the west of India has been shown to vary from three to six months. And further, the movements at the eastern stations are sometimes much le $\mathrm{s}$ or much greater than those which took place at the western station. Evidently, then, there is some influence which tends to produce ir regularities in the eastward transmission of the abnormal movements; and this influence must be discovered and its occurrence foreseen and allowed for before the Zanzibar curve could be used for the purpose of predicting the nature of the movements at Belgaum and Bombay, and, as a consequence, the nature of the seasons in Western India.

A second inspection of the curves seems to indicate that not only are there abnormal movements which travel from the western station to the eastern ones, but there are also variations which are felt at all the three stations simultaneously. Thus in the months of July, I880, June, 1881, and January, I882, there are simultaneous upward bends of the curves at all the three stations. And again in the months of May, August, and November, 188I, there are simultaneous dow nward movements at all the three stations. These simultaneous movements are especially observable if the unsmoothed monthly abnormals (the thin dotted lines) be referred to instead of the : moothed curve (the thick continuous line). They are then seen to be exceedingly numerous-so numerous, indeed, that they may well be supposed to frequently mask the non-simultaneous or travelling movements, and cause those movements apparently to present many irregularities. The following table shows concisely the times when upward and downward movements have taken place at all the three stations simultaneously :-

TABLE III.-At Zanzibar, Belgaum, and Bombay simultaneous Barometric Abnornal Movements

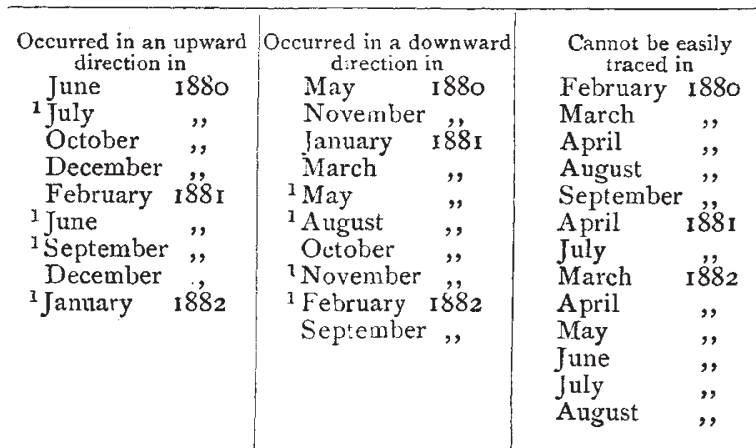

Thus out of thirty-tw. months there were nineteen in which it can be seen that simultaneous movements occurred at the three stations ; and ont of the:e nineteen months there were eight in which the movements were very distinct. In the remaining eleven months sut of the nineteen the movements were not so prominent or well marked, but were always distinct enough to be readily recognised, and it does not seem unreasonable to suppose that the influence of such movements may have been felt in some if not all of those months in which they cannot te easily traced; that in fact the simultaneous movements may have been so small as to show themselves only in an excessive or deficient movement, upward or downward as the case may have been, of the curve which represents the non-simultaneous or travelling movements. In any case eight of these movements appear to be sufficiently distinct to disallow of doubt; and considering that Zanzibar is about 2500 miles distant from Belgaum, the fact seems to be interesting.

$$
\text { Bombay, January ro Acg. Meteorological Reporter for }
$$$$
\text { A. N. PEARSON, }
$$

(To be continued.)

\section{THE INSTITUTION OF MECHANICAL ENGINEERS IN BELGIUM}

THE Institution of Mechanical Engineers has this year held its summer meeting in Belgium-the first time that it has crossed the Channel, except on the two occasions of the exhibitions in Paris. The reception was organised by the Association of Engineers from Liége University (Honorary Secretary, M. Edouard de Laveleye), and was of the most cordial character. The great works of Belgium were thrown open without reserve, and numerous excursions were organised to visit them. Amongst those specially to be noticed are the colossal establishment of the Cockerill Society at Seraing, the great iron and steel works at Ougrée and Sclessin, the vast zine works of the Vieille Montagne Company, the cloth factories at Verviers, and the splendid collieries of Mariemont, probably the finest examples of colliery plant in the world. Space forbids our entering into a description of these works, and we shall confine ourselves to the papers read, so far as these possess more than a technical interest.

The proceedings opened on Monday evening, July 23, with a reception by the Mayor of Liége, after which the president, Mr. Percy Westmacott, delivered an interesting and suggestive address. After speaking of the great modern extension of Belgian industries, and of the debt which the world owes to the inventive skill of the engineer for providing those processes on which all trades are dependent for cheap and rapid production, he went on to develop his special theme, namely, the advantage of High Speed and its connection with high workmanship. The following extracts are well worth quoting :-

"The keen and continual attention bestowed upon the work to be done, and the means of doing it, has led engineers in general to regard speed of production as one of the first elements of success. There is indecd a proverb, 'more haste, less speed ;' but this, thouyh true of human labour, which ceases to ${ }^{I}$ In these months the movements are very distinct. 